\title{
PERANCANGAN SISTEM INFORMASI SECARA REAL TIME UNTUK ANALISIS OPERATING TIME MESIN
}

\author{
Priyo Ari wibowo1 ${ }^{1}$, Albertus Tomi2 ${ }^{2}$ \\ ${ }^{1,2}$ Program Studi Teknik Industri STT Wastukancana \\ Jl. Alternative Bukit Indah - Purwakarta \\ ${ }^{1}$ priyoariwibowo@stt-wastukancana.ac.id
}

\begin{abstract}
Abstrak
Teknologi industri mengalami kemajuan yang sangat pesat dalam pengolahan bahan, peralatan dan proses yang terintegrasi dengan perangkat komputer, sehingga telah merubah sistem manual menjadi serba otomatis. Saat ini, perkembangan yang pesat dari teknologi sensor, interkoneksi, dan analisis data memunculkan gagasan untuk mengintegrasikan seluruh teknologi tersebut ke dalam berbagai bidang industri, tahapan ini dikenal revolusi industry keempat atau era industri 4.0. Teknologi informasi di era ini sangat berpengaruh dan memudahkan manusia dalam memproduksi, mengolah data dan menyebarkan informasi. Selain dari kecepatannya, kinerja mesin juga lebih terjamin keakuratan serta keberhasilannya dalam beroperasi. Tujuan dari penelitian ini adalah untuk merancang sebuah sistem informasi di lini produksi berkaitan dengan informasi operating time dan downtime yang terjadi, sehingga kinerja mesin lebih terkontol secara cepat dan dapat dievaluasi saat itu juga (real time). Kecepatan informasi tersebut akan memudahkan pengambilan keputusan atau perubahan strategi secara cepat. Downtime adalah sumber utama yang menyebabkan kehilangan produktivitas sehingga dengan penanganan downtime yang lebih cepat, perusahaan bisa memperoleh hasil produksi dengan signifikan.
\end{abstract}

Kata kunci : Industry 4.0, operating time, down time, kinerja mesin, produktivitas

\section{Pendahuluan}

Pada revolusi industri keempat, menjadi lompatan besar bagi sektor industri, dimana teknologi informasi dan komunikasi dimanfaatkan sepenuhnya.Tidak hanya dalam proses produksi, melainkan juga di seluruh rantai nilai industri sehingga melahirkan model bisnis yang baru dengan basis digital guna mencapai efisiensi yang tinggi dan kualitas produk yang lebih baik [1]. Penggunaan sensor di mana-mana, perluasan komunikasi dan jaringan nirkabel, penyebaran robot dan mesin yang semakin cerdas - serta peningkatan daya komputasi dengan biaya lebih rendah dan pengembangan analitik berpotensi mengubah cara barang diproduksi.

Pemberian nama judul-judul bab, kecuali bab Pend Revolusi industri digital baru ini menjanjikan peningkatan fleksibilitas di bidang manufaktur, kustomisasi massal, peningkatan kecepatan, kualitas yang lebih baik, dan peningkatan produktivitas. Namun untuk menangkap manfaat ini, perusahaan perlu berinvestasi dalam peralatan, teknologi informasi dan komunikasi (TIK) dan analisis data serta integrasi arus data di seluruh rantai nilai global. Namun tantangan tetap ada. Kebutuhan investasi, perubahan model bisnis, masalah data, pertanyaan hukum tentang kewajiban dan kekayaan intelektual, standar, dan ketidaksesuaian keterampilan adalah beberapa tantangan yang harus dipenuhi jika ingin memperoleh manfaat dari manufaktur baru dan teknologi industri. Jika kendala ini dapat diatasi, Industri 4.0 dapat membantu membalikkan penurunan industrialisasi di masa lalu dan meningkatkan total nilai tambah dari manufaktur menjadi $20 \%$ yang ditargetkan dari semua nilai tambah pada tahun 2020 [2].

Penelitian ini bertujuan untuk merancang sebuah sistem informasi di lini produksi berkaitan dengan informasi operating time, sehingga kinerja mesin lebih terkontol secara cepat dan dapat dievaluasi saat itu juga (real time).

\section{Tinjauan Pustaka}

\subsection{Sistem Informasi}

Sistem adalah sekelompok elemen-elemen yang terintegrasi dengan tujuan yang sama untuk mencapai suatu tujuan. Terdiri dari sejumlah sumber daya manusia, material, mesin, uang dan informasi. Sumber daya tersebut bekerja sama menuju tercapainya suatu tujuan tertentu yang ditentukan oleh pemilik atau manajemen. (Yakub, 2012;1). Informasi (information) adalah data yang diolah menjadi bentuk lebih berguna dan lebih berarti bagi yang menerimanya atau data yang diproses sedemikian rupa sehingga meningkatkan pengetahuan seseorang yang menggunakan. Sistem apapun tanpa ada informasi tidak akan berguna, karena sistem tersebut akan mengalami kemacetan dan akhirnya berhenti. Informasi dapat berupa data 
mentah, data tersusun, kapasitas sebuah saluran informasi dan sebagainya. (Yakub,2012;8).

Sistem informasi, seperangkat komponen terintegrasi untuk mengumpulkan, menyimpan, dan memproses data dan untuk menyediakan informasi, pengetahuan, dan produk digital. Perusahaan bisnis dan organisasi lain mengandalkan sistem informasi untuk menjalankan dan mengelola operasi mereka, berinteraksi dengan pelanggan dan pemasok mereka, dan bersaing di pasar. Sistem informasi digunakan untuk menjalankan rantai pasokan antar organisasi dan pasar elektronik. Misalnya, perusahaan menggunakan sistem informasi untuk memproses akun keuangan, mengelola sumber daya manusia, dan menjangkau pelanggan potensial mereka dengan promosi online. Banyak perusahaan besar dibangun seluruhnya di sekitar sistem informasi.

\subsection{Operating Time}

Operation time merupakan hasil pengurangan loading dengan waktu down time(non operation time),dengan kata lain operation time adalah waktu operasi tersedia (avaibility time)setelah waktu downtime mesin keluarkan dari total avaibility time yang di rencanakan, Down time mesin adalah waktu proses yang seharusnya digunakan mesin akan tetapi karena adanya gangguan pada mesin/peralatan (equipment failures) mengakibatkan tidak ada output yang di hasilkan downtime meliputi mesin berhenti beroperasi akibat kerusakan mesin/peralatan , penggantian cetakan (dies), pelaksanaan prosedur set-up dan adjustment dan lain lainya..

Operating time dan downtime merupakan satu kesatuan data yang dihasilkan dari pergerakan proses mesin. Downtime sendiri terbagi lagi menjadi 2 jenis : scheduled downtime dan unscheduled downtime. Scheduled downtime biasanya dilakukan utk tindakan Preventive Maintenance, unscheduled downtime merupakan kegagalan suatu equipment ketika sedang beroperasi (breakdown).

Data merupakan komponen penting bagi suatu analisis. Dengan adanya data pengambilan keputusan menjadi lebih mudah dan tepat. Dari data yang sudah ada, operator dapat melakukan proses analisis mesin dengan mudah dan tetrstruktur. Analisa pada mesin yang mengalami downtime sangat penting bagi proses produksi dan efektifitas produksi ke depan

\subsection{Kinerja Mesin}

Pengertian kinerja mesin adalah kemampuan mesin untuk menghasilkan suatu indicator tertentu seperti mesin apakah mengalami kerusakan, apakah mesin dapat bekerja terus menerus dalam periode waktu tertentu. Kinerja mesin sangat terkait dengan produktivitas yang dicapai. Produktivitas, daya produksi, atau keproduktifan merupakan istilah dalam kegiatan produksi sebagai perbandingan antara luaran (output) dengan masukan (input).Menurut Herjanto, produktivitas merupakan suatu ukuran yang menyatakan bagaimana baiknya sumber daya diatur dan dimanfaatkan untuk mencapai hasil yang optimal. Produktivitas dapat digunakan sebagai tolok ukur keberhasilan suatu industri atau UKM dalam menghasilkan barang atau jasa. Sehingga semakin tinggi perbandingannya, berarti semakin tinggi produk yang dihasilkan. Ukuran-ukuran produktivitas bisa bervariasi, tergantung pada aspek-aspek output atau input yang digunakan sebagai agregat dasar, misalnya: indeks produktivitas buruh, produktivitas biaya langsung, produktivitas biaya total, produktivitas energi, produktivitas bahan mentah, dan lain-lain

Siklus produktivitas merupakan salah satu konsep produktivitas yang membahas upaya peningkatan produktivitas terus-menerus. Ada empat tahap sebagai satu siklus yang saling terhubung dan tidak terputus antara lain : Pengukuran, Evaluasi, Perencanaan, Peningkatan. Produktivitas yang diperhitungkan hanya produk bagus yang dihasilkan saja, jika suatu work center banyak mengeluarkan barang cacat dapat dikatakan work center tersebut tidak produktif. Keempat kegiatan tersebut sudah menjadi dasar industri dalam melakukan peningkatan produktivitas. Siklus produktivitas digunakan sebagai dasar perbaikan masalah produksi terutama pada skala industri. Beberapa permasalahan yang menyebabkan penurunan produktivitas perusahaan adalah:

a. Tidak ada evaluasi produktivitas

b. Keterlambatan pengambilan keputusan oleh manajemen

c. Motivasi rendah dalam pekerjaan.

d. Perusahaan tidak mampu berkompetisi dan beradaptasi pada kemajuan teknologi dan informasi.

\section{Metodologi Penelitian}

\subsection{Tahapan Penelitian}

Kerangka pemikiran ditunjukkan pada Gambar 1. Pengamatan awal dilakukan terhadap proses bisnis area penelitian di perusahaan. Berdasarkan hasil observasi, ditemukan masalah inefisiensi atau ketidaktepatan dalam evaluasi harian, mingguan dan bulanan.Setiap data keluaran mesin yang ada masih memerlukan pengolahan data.

Langkah selanjutnya adalah merancang sistem pemantauan produksi otomatis untuk mengatasi masalah tersebut. Metode desain system diambil dari [9]. Ada pertanyaan panduan yang perlu ditentukan. dimana salah satu pertanyaan tersebut adalah tentang penentuan metode pengumpulan atau akuisisi data.

Metode akuisisi diambil dari [10]. Pada langkah pertama, sensor yang sesuai harus ditentukan untuk mengukur kinerja proses pemesinan atau untuk mendeteksi data luaran mesin. 
Sinyal yang dihasilkan oleh sensor perlu diolah untuk menghasilkan sinyal yang berkualitas dan baik bebas dari keterlambatan data. Sinyal tersebut kemudian diolah kembali dengan fitur deskriptor tertentu sehingga informasi yang terkandung dapat dipahami oleh pengguna sebagaimana dimaksud. Hasil pemrosesan sinyal dengan deskriptor kemudian perlu ditampilkan agar pengguna dapat mengakses dan melihat informasi dengan mudah untuk tujuan analisis.

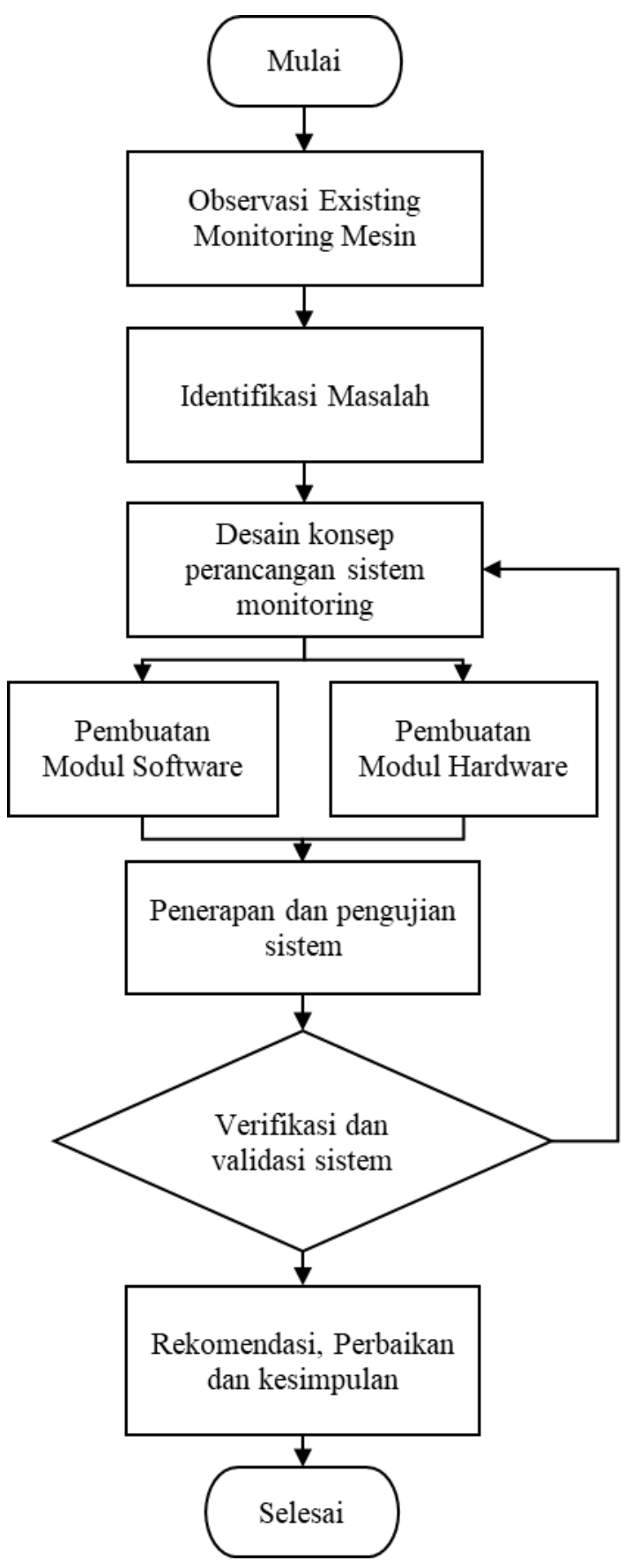

Gambar 1. Tahapan Penelitian

\subsection{Identifikasi Proses}

Sistem monitoring secara real time adalah alat produksi yang membantu manajemen untuk mengumpulkan dan mendistribusikan informasi kepada semua orang di shop floor saat proses sedang berlangsung. Sistem monitoring real time adalah penting dalam membantu industri mencapai tujuan produksi, menjadikan downtime yang berkurang dan peningkatan hasil.

Mengembangkan sistem yang andal dan jujur dalam data, menangkap dan menampilkannya bukanlah faktor, namun ada batasan tertentu pada perangkat yang tersedia. Masalah-masalah ini menjadi kritis bila ada intervensi manusia dalam proses produksi. Penelitian ini dilakukan untuk mengembangkan system monitoring secara real time menggantikan pengawasan manusia di jalur produksi. Informasi dari lini produksi sangat penting untuk meningkatkan hasil produksi di semua tahap [7]. Menangkap dan menafsirkan data produksi ini tanpa intervensi manusia merupakan tantangan utama bagi manajemen.

Proses monitoring ditunjukan pada Gambar 2. Proses dimulai dari PPIC mengatur perencanaan dan penjadwalan proses produksi. Informasi tentang urutan proses produksi dan jadwal untuk setiap item produk yang dimanifestasikan dalam bentuk lembar pemantauan produksi. Tahapan selanjutnya adalah proses desain dengan luaran lembar gambar,yang di distribusikan ke proses selanjutnya untuk pengadaan material dan pembuatan desain program mesin.Tahapan selanjutnya setelah lembar data program selesai, kemudian proses machining berjalan. Dalam proses machining beberapa data perlu dicatat diantaranya data operating time, loss time dan error time. Data - data tersebut diinput secara manual dengan melihat data dilayar mesin, sehingga tindakan atau keputusan sesuai dengan waktu kapan data tersebut dicatat dan dilaporkan ke penanggungjawab proses.

Tahapan setelah proses machining adalah melakukan verifikasi pengecekan hasil secara dimensi maupun visual produk. Jika tidak memenuhi kriteria hasil, maka proses dievaluasi oleh penanggunjawab desain program. Jika sesuai proses finish mesin selesai. Data data yang tercatat,selain di formulir tercetak juga dicatat dalam database perusahaan melalui excel. Data waktu penyelesaian, pengoperasian, waktu produksi nyata dan validasi dilakukan sesuai data yang sudah diolah.

Pengolahan data dalam database sangat menentukan tindakan selanjutnya. Namun kondisi pengolahan data yang memerlukan waktu dan dilakukan pada siklus akhir shift atau bahkan mingguan, membuat Analisa dan evaluasi masalah saat terjadi, tidak dapat diselesaikan dengan cepat dan tepat. Dampak dari masalah tersebut adalah terjadinya losstime berlebih saat proses machining. 
Dengan demikian perlu dilakukan pengembangan system monitoring yang lebih efektif untuk mengolah data dari mesin seperti operating time, loss time, error time menjadi data visual yang dapat dilihat tiap waktu. Hasil tampilan visual perlu di desain dengan tampilan peringatan yang jelas tanpa harus melihat detail nilai waktu yang ditampilkan.

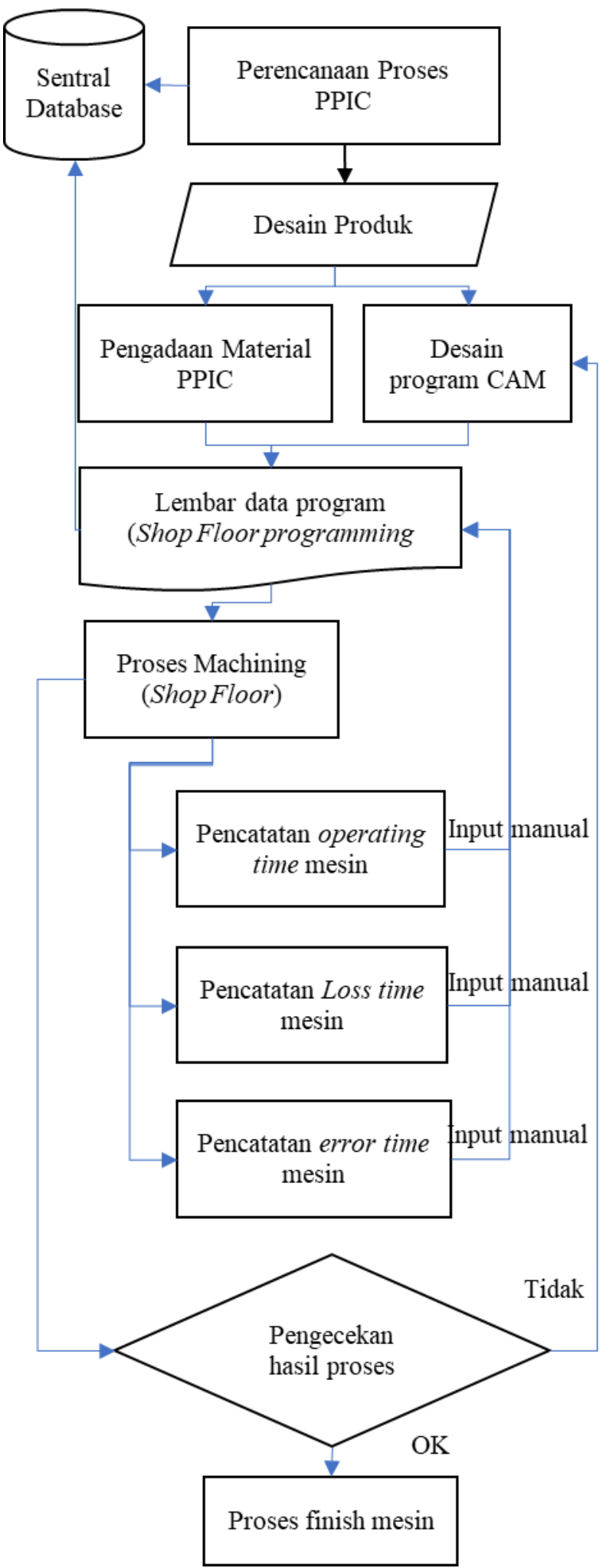

Gambar 2. Existing Proses Monitoring

\section{Perancangan Sistem dan Pembahasan}

\subsection{Desain Sistem}

Sistem informasi yang dirancang dengan baik bertumpu pada fondasi yang yang mendukung perubahan responsif, kelincahan organisasi atau inisiatif administratif. Dikenal sebagai infrastruktur sistem informasi, fondasinya terdiri dari jaringan telekomunikasi inti, database dan gudang data, perangkat lunak, perangkat keras, dan prosedur yang dikelola oleh berbagai spesialis. Membangun dan memelihara infrastruktur yang kompleks membutuhkan perencanaan ekstensif dan implementasi yang konsisten untuk menangani inisiatif strategis perusahaan, transformasi, merger, dan akuisisi. Infrastruktur sistem informasi harus dibangun untuk menciptakan pilihan yang berarti untuk pengembangan perusahaan di masa depan.

Ketika diatur menjadi satu kesatuan, sistem informasi spesifik yang mendukung operasi, manajemen, dan pekerjaan pengetahuan membentuk arsitektur sistem organisasi. Jelas, rencana strategis umum jangka panjang organisasi harus dipertimbangkan ketika merancang infrastruktur dan arsitektur sistem informasi. Perancangan sistem informasi dilakukan berdasarkan hasil pemodelan sistem.

Tahap perancangan yang dilakukan dalam penelitian ini menggunakan langkah-langkah berikut:

a. Analisis terhadap aliran data dan informasi.

b. Perancangan database sistem.

c. Perancangan user interface.

Dalam menangani masalah untuk memonitor dan mengevaluasi kinerja mesin berdasarkan aktual kinerja mesin (logsheet) Secara garis besar, proses yang akan dilakukan oleh sistem untuk menangani masalah tersebut dapat dilihat pada desain arsitektur seperti gambar 3 .

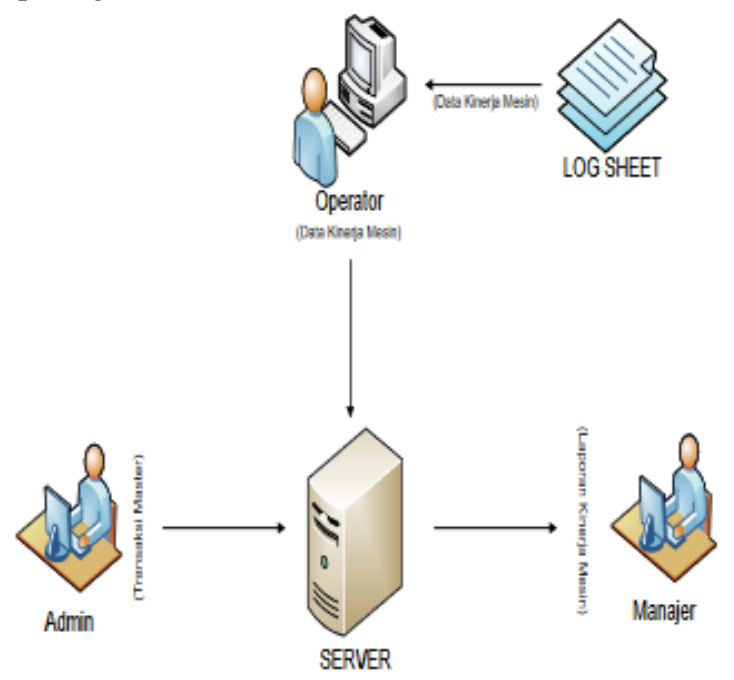


Gambar 3. Desain Arsitektur Sistem Informasi

\subsection{Pembuatan Modul Hardware}

Tahapan Pembuatan modul hardware transmitter diawali dengan desain schematic, layout PCB, Etching PCB sampai dengan perakitan part.

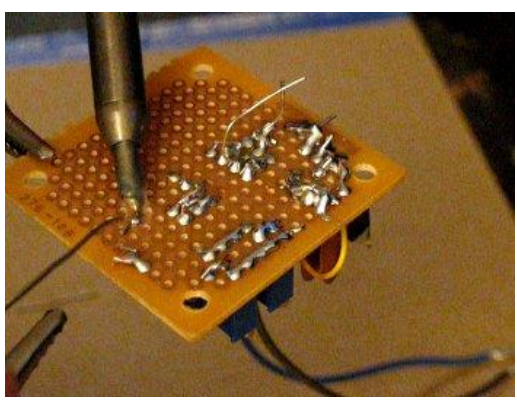

Gambar 4. Perakitan part

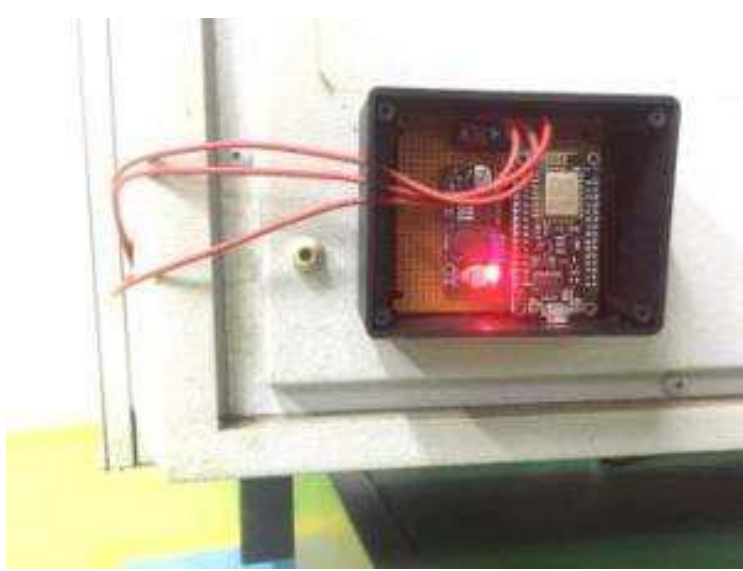

Gambar 5. Hardware Transmitter Mesin

\subsection{Pembuatan Modul Software}

Seperti yang terlihat pada Gambar 5, perangkat pemantauan terletak di dekat indicator panel lampu mesin. Ketika mesin beroperasi (operating time), berhenti (Loss time) ataupun terjadi alarm (error time), maka indicator panel lampu hijau , kuning dan merah akan mengirim datake transmitter, kemudian transmitter akan mengirim data ke server melalui router. Data dari server kemudian diolah oleh aplikasi dengan tampilan visual ditunjukkan pada gambar gambar berikut

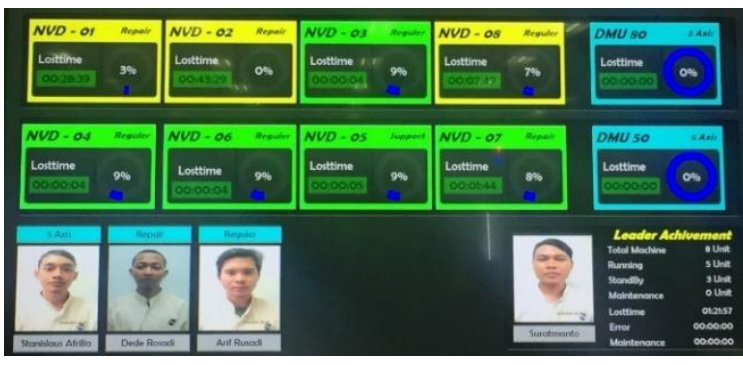

Gambar 6. Display Monitoring Real Time

Tampilan ini dapat memonitoring waktu kerja mesin, orang dan memberikan peringatan loss time.

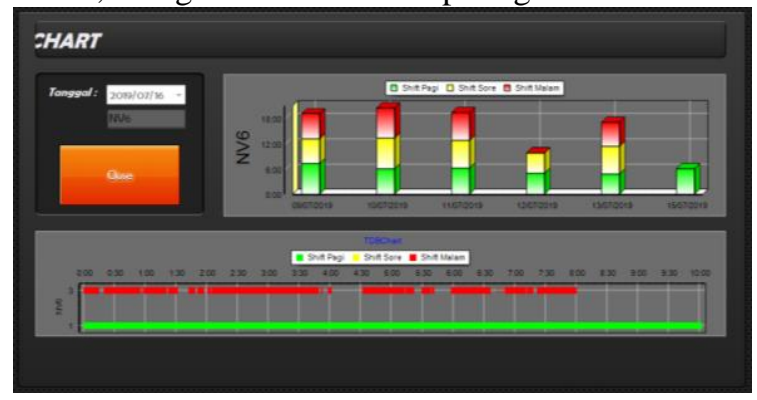

Gambar 7. Display Grafik Pencapaian

\subsection{Hasil dan Pembahasan}

Verifikasi sistem telah dilakukan dengan menguji dan mengevaluasi semua fungsi dan fitur yang dirancang. Proses menunjukkan hasil yang memuaskan. Selanjutnya dilakukan proses validasi dengan mengimplementasikan sistem disesuaikan dengan kondisi sebenarnya. Proses validasi melibatkan operator, supervisor dan staff PPIC..

Berdasarkan hasil validasi, sistem yang diusulkan dapat diimplementasikan dengan baik di area machining. Data manual pencatatan dan pengetikan oleh operator dan supervisor sekarang tidak lagi diperlukan. Ini dapat mencegah keterlambatan analisa, kesalahan dan manipulasi data masukan. Staff atau PPIC dapat memanfaatkan data untuk mereview jadwal dan mengambil keputusan yang sesuai data yang lebih akurat. Data waktu pengerjaan dan waktu pengerjaan berguna bagi supervisor untuk membuat penilaian yang lebih baik kinerja operator. Selain itu, supervisor juga dapat memantau riwayat penggunaan dan kapasitas mesin. Artinya supervisor dapat dengan cepat memastikan beban kerja shop floor yang menjadi tanggung jawabnya. Supervisor, PPIC atau staf manajemen tingkat yang lebih tinggi dapat melakukan fungsi pengawasan dimanapun dan kapanpun secara real time atau saat itu juga selama masih dalam jaringan perusahaan.

\section{Kesimpulan dan Saran}

\subsection{Kesimpulan}

Setelah melakukan perancangan sistem, implementasi, analisa dan evaluasi, dari program aplikasi Sistem Informasi Monitoring dan Evaluasi Kinerja Mesin ini maka kesimpulan:

a. Sistem Informasi Monitoring dan Evaluasi Kinerja Mesin yang dibangun ini dapat memonitor data-data kinerja masing-masing mesin dan dapat mengevaluasi kinerja masingmasing mesin secara real time 
b. Data yang dapat diolah secara otomatis diantaranya operating time, loss time, error time serta indeks pencapaian masing - masing shift

c. Kontrol terhadap kinerja mesin dan operator dapat di evaluasi tiap jam ataupun harian

\section{Daftar Pustaka:}

Amsler, G. M., Findley, H. M., \& Ingram, E., (2009): Performance monitoring: guidance for the modern workplace. Supervision, 70, 12-19

A. Snatkin, K. Karjust, J. Majak, T. Aruväli and T. Eiskop, (2013): Estonian Journal of Engineering 19 (1), pp.62-75

Chaffey, Dave dan Wood, Steve.(2005): Business Information Management. England: Prentice Hall.

(2015) Industry 4.0: Digitalisation for productivity and growth [Online]. Available: https://www.europarl.europa.eu/

Industry 4.0 (2015): the future of productivity and growth in manufacturing industries, Boston Consulting Group.

Industry 4.0 (2014): the new industrial revolution, how Europe will succeed, Roland Berger Consultants.

(2017) Information System [Online]. Available: https://www.britannica.com/topic/informationsystem

(2018) Making Indonesia 4.0 [Online]. Available: https://bsn.go.id/

O'Brien, J.A., and Marakas, G. (2010): Introduction to Information Sistems. 5th Edition. New York: McGraw-Hill.

S. K. Subramaniam, S. H. Husin, Y. Yusop, A. H. Hamidon, (2008): "Data collection using a real time production monitoring system for factors affecting production lines ", Journal of Science and Technology in the Tropics 4 Page(s):129134.

Stairs, Ralph; Reynolds, George;.(2012): Fundamental of Information Sistems. 6th Edition. USA: Cengage Learning

(2018) Strategi RI Masuki-Revolusi Industri Ke 4K [Online]. Available: https://kemenperin.go.id/

Susie (Yamagishi) Werner, (2004): http://www.isixsigma.com/dictionary/Andon585.htm

Tom Pherson, June 2006, 'Overall Equipment Effectiveness \& Real-Time Visual Management Critical Lean Tools'Intelligent Manufacturing Solutions,Page(s):1-18.

Whitten, Jeffrey L.(2007). Sistem Analysis and Design Methods 7th ed. New York: McGrawHill. 